\title{
Common bacterial cultures from oral mucosa after hematopoietic stem cell transplantation: dependence on the patient characteristics and therapeutic factors
}

\author{
Alexei B. Chukhlovin ${ }^{1}$, Anna A. Spiridonova ${ }^{2}$, Irina B. Baranova ${ }^{3}$, Artur P. Grigoriants ${ }^{3}$, Maria D. Vladovskaya ${ }^{1}$, \\ Ludmila S. Zubarovskaya ${ }^{1}$, Boris V. Afanasyev ${ }^{1}$ \\ ${ }^{1}$ Raisa Gorbacheva Memorial Research Institute of Pediatric Oncology, Hematology and Transplantation, St. Petersburg, Russia \\ ${ }^{2}$ Department of Clinical Microbiology, Pavlov University, St. Petersburg, Russia \\ ${ }^{3}$ Department of Orofacial Surgery, Pavlov University, St. Petersburg, Russia
}

Prof. Alexei B. Chukhlovin, Raisa Gorbacheva Memorial Research Institute of Pediatric Oncology, Hematology and Transplantation, Pavlov University, L. Tolstoy St. 6-8, 197022, St. Petersburg, Russia
Phone: +7(921) 3250094

E-mail: alexei.chukh@mail.ru

Citation: Chukhlovin AB, Spiridonova AA, Baranova IB et al. Common bacterial cultures from oral mucosa after hematopoietic stem cell transplantation: dependence on the patient characteristics and therapeutic factors. Cell Ther Transplant 2019; 8(4): 49-56.

\section{Summary}

Normal aerobic and facultative anaerobic microbiota colonizing oral mucosa is usually identified at clinical laboratories. Its composition may be important index of immunocompromised conditions. These parameters are scarcely studied in patients undergoing hematopoietic stem cell transplantation (HSCT). The aim of this work was to evaluate incidence of common aerobic and facultative anaerobic microbiota cultured from oral samples taken before HSCT and, by clinical indications, within 4 months after the treatment.

\section{Patients and methods}

We evaluated results of bacterial cultures from oral smears taken in 202 patients with oncohematological and inborn diseases at the age ranging from 1 to 69 years subjected to allogeneic HSCT. The analysis was performed for 3 age groups: 1-5, 6-14, 15-21, and $>22$ years old.

\section{Results}

In total observation group of 630 oral samples, the bacterial cultures proved to be positive in $61.8 \%$ of specimens. The most common microorganisms were as follows: S.viridans 245/630 (38.9\%); K.pneumoniae $42 / 630$ (6.7\%); S.epidermidis 120/630 (19.1\%); Neisseria spp. 66/630 (10.5\%); Corynebacterium spp. 78/630 (12.4\%). The incidence of microbial detection was time- dependent, with significant decrease in S.epidermidis, Corynebacterium spp. and Klebsiella spp. during $1^{\text {st }}$ month posttransplant which could be explained by early effective antibacterial decontamination since the time of conditioning in early posttransplant period. We have shown that the frequency of positive tests for S.viridans and K.pneumoniae in these samples were different for distinct age groups, i.e., the positivity rates were significantly higher in youngest children (up to 5 years old) and in adult patients ( $>22$ years old), as compared with elder children and adolescents. Incidence of K.pneumoniae in oral samples was found to be sufficiently increased 2-3 months after HSCT, being associated with severe infectious complications, with broad antibiotic resistance in most culturable Klebsiella isolates from the patients. For clinical indications, teeth extraction was made in 10 cases during $1^{\text {st }}$ month after HSCT, with Pseudomonas aeruginosa in 3 samples, S.viridans in 2 cases isolated from the local gum wounds. In conclusion, the immunotoxic effects of cytostatic therapy and microbiota analysis post-HSCT deserve further studies, including biodiversity analysis of oral microbiota by means of $16 \mathrm{~S}$ rRNA gene sequencing. These results may represent a basis for rational antibacterial therapy in HSCT.

\section{Keywords}

Oncohematology, children, chemotherapy, hematopoietic stem cell transplantation, bacterial cultures, risk factors. 


\section{Introduction}

Normal microbiota colonizing mucosal surfaces is usually identified at clinical laboratories by means of aerobic cultures in standard agar cultures. It comprises, mostly, saprophytic and oppor-tunistic bacteria. In particular, the microflora of normal oral mucosa is well known, and the most common bacterial species are identified [1,2]. Members of normal oral microbiota exist as com-mensal flora in a symbiotic state within host tissue, thus suppressing colonization with more path-ogenic bacterial species as presented in excellent review by Hull, Chow [1]. The most common aerobic species isolated in clinical cultures from oral cavity and oropharynx mucosa include Gram-positive Streptococci (e.c., S.viridans), Staphylococcus epidermidis, Corynebacterium spp., Neisseria $s p p$., etc. Moreover, oral cavity, and, especially, ginvival mucosa contain multiple an-aerobic flora which is represented by hundreds species, most of which could be detected only by DNA-based diagnostic techniques [3].

Intensive chemotherapy of cancer and, especially, hematopoietic stem cell transplantation (HSCT) are followed by severe immunosuppression. I.e., pronounced neutro-and lymphopenia develops within 1-2 weeks after HSCT, accomplished by reactivation of endogenous viruses, as well as opportunistic bacteria and nosocomial pathogens which may colonize different mucosal surfaces and replace conventional microflora, thus leading to local dysbacteriosis [4]. Local infections are a common consequence of severe leukopenia. E.g., a previous study of 143 HSCT pa-tients [5] has shown nosocomial bacterial infections in ca. $25 \%$ of cases, especially, septicemia (43\%), and respiratory infections. Some pathogenetic links between infections and oral mucositis were suggested by Laheji et al. [6].

In most oncohematological clinics, the bacterial cultures from local biomaterials are performed by clinical indications, e.g., due to febrile neutropenia or local inflammatory loci. Surveillance microbial diagnostics is also sometimes implemented, however, without any clinical benefits [7]. Majority of these studies concern reactivation/reinfection with different viruses, in particular, herpesviruses, parvoviruses etc. Studies in bacterial infections mainly deal with isolation of aerobically cultivated pathogenic strains, their toxins and antibiotic resistance, mainly, Pseudomonas spp., Klebsiella pneumoniae, Clostridium difficile or enteropathogenic E.coli infections.

To our knowledge, there were only few studies of microbial landscape in oral mucosa at different periods after HSCT [7]. In most cases, these studies are epidemiologically oriented, and provide relative frequencies of local pathogenic microorganisms in HSCT patients, and their potential correlations with clinically significant infections [8].

Only few works concern time dynamics of the microbial landscape in the patients after HSCT, however, lacking sufficient data on possible relations between the shifts of oral microbiota and common HSCT complications, i.e., local infections, oral mucositis, or acute graft-versus-host disease (aGVHD).

The aim of the present study was to estimate the frequency of cultivable aerobic microflora obtained from oral mucosa smears taken before HSCT and during 4 months posttrans- plant. We have evaluated time course for the most common microorganisms, as well as probable interactions between the frequency of their detection rates and occurrence of characteristic complications after HSCT, including mucositis, febrile neutropenia, acute GVHD, and clinically significant infectious complications.

\section{Patients and methods}

In the present study, we have evaluated results of clinical bacterial cultures from 630 smears of the oropharynx and tongue taken from 202 patients at the age of 1 to 69 (108 males and 94 females) subjected to allogeneic HSCT at the R. Gorbacheva Memorial Institute of Children Oncology, Hematology and Transplantation from January 2016 to December 2017. Allogeneic HSCT was performed for acute myeloblastic leukemia (AML, n-63), chronic myeloid leukemia (CML, $\mathrm{n}=28$ ), acute lymphoblastic leukemia (ALL, $\mathrm{n}=34$ ), severe aplastic anemia (SAA, $n=22)$, refractory anemia $(R A$, $\mathrm{n}=6$ ), plasma cell dysplasia (7 cases), primary myelofibrosis (PMF, $\mathrm{n}=10)$. Inborn genetic disorders were treated in 9 children, Hodgkin lymphoma, in 6 patients, non-Hodgkin's lymphomas, in 4 cases, juvenile myelomonocytic leukemia, in 3 patients; polycythemia vera, in 2 patients, essential thrombocytopenia, etc. Myeloablative conditioning regimens were performed in for 122 patients, and non-myeloablative protocols were applied in 80 cases. Bone marrow was used as a source of stem cells in 97 cases, and peripheral stem cells, in 105 patients. HSCT was carried out from related HLA-compatible donors $(n=35)$, related haploidentical donors (33 patients), or unrelated HLA-matched donors (112 cases). Patients or their close relatives signed appropriate informed consent for their participation in the research program, and usage of their personal medical data for the scientific evaluation. The smears for bacteriological studies were taken from oropharynx or tongue. Subsequent sampling was made before HSCT and within 120 days (4 months posttransplant), according to clinical indications from the attained physicians. The biomaterials were conserved, stored and processed at the Department of Clinical Microbiology, being seeded on agar plates and cultured on the conventional nutrient media under aerobic conditions.

Statistical analysis included the patients with at least 1 result before HSCT, and 2 results within 4 months posttransplant. All the data on clinical characteristics of the patients, HSCT parameters, conditioning therapy, posttransplant complications, and bacterial cultures were taken from the hospital reports of R. Gorbacheva Memorial Institute, and laboratory database at the $1^{\text {st }}$ St. Petersburg State I. Pavlov Medical University. Statistical evaluation was performed by means of the STATISTICA 5.0 software, by means of non-parametric single-factor analysis using Hi-square criterion and Pearson correlation quotients to evaluate significance of differences between the samples. In some series, parametric methods were used using Student t-test.

\section{Results}

\section{Common bacteria detectable in oral cavity}

Total sample included 630 cultures from oral smears, with positive results for 389 specimens (61.8\%). One microbial 
species was detected in 250 cases; 2 species, в 117 cultures, and 3 microbial species, in 22 cultures. The most common microorganisms were as follows: S. viridans 245/630 (38.9\%); K.pneumoniae 42/630 (6.7\%); S.epidermidis 120/630 (19.1\%); Neisseria spp., 66/630 (10.5\%); Corynebacterium spp., 78/630 $(12.4 \%)$. Other bacteria were detected in $<1 \%$ of the cultures (S. saprophyticus., Pseudomonas spp., S.faecalis, S.faecium). For statistical reasons, only 5 most common bacterial species were included into further analysis, i.e., S.viridans, K.pneumoniae, S.epidermidis, Neisseria spp., Corynebacterum spp.

\section{Age factor}

Frequency of the five common bacterial species in the oral cavity smears is shown in Table 1 . For the age groups of $0-5$, 6-14, 15-21 y.o., and adult persons (>22 y.o.), some significant age dependencies were revealed. I.e., S.viridans detection was maximal in smaller children ( 0 to 5 years old), as compared to the groups of $6-14$ and $15-21(\mathrm{p}<0.02)$, then showing an increase in adult patients. Similar tendency was seen for Klebsiella pneumoniae, with higher detection rates in small children and adult patients.

\section{Time dependence of microbial detection}

Frequency of positive cultures was time-dependent, and varied for different microorganisms (Table 2). However, a significant drop was evident for all the detectable microbial species during $1^{\text {st }}$ month posttransplant, most obviously, due to intensive antibacterial prophylaxis started before HSCT. The early suppression was most pronounced for S.viridans, and S.epidermidis, a normal component of oral microflora. Interestingly, an initial marginal decrease of K.pneumoniae detection was followed by its sharp increase at 2-4 months (Fig. 1).

\section{HSCT parameters}

As seen from Table 3, we have not found any significant associations between the frequency of positive cultures of common oral microbes, and source of stem cells (bone marrow $v s$ peripheral stem cells), or type of HSCT (related $v s$ unrelated $v$ s haploidentical HSCT). Meanwhile, decreased detection rates of S.epidermidis proved to be significantly associated with more intensive (myeloablative) therapy, as compared to reduced-intensity regimens (Table 3). As expected, K.pneumoniae was associated with clinically significant infectious complications of either location.

Table 1. Detection of the common bacterial species in the specimens from oral cavity in children and adults at the whole observation period (-60 to +120 days post-HSCT)

\begin{tabular}{|l|l|l|l|l|l|}
\hline Age groups, years old & $\mathbf{1}$ & $\mathbf{2}$ & $\mathbf{3}$ & $\mathbf{4}$ & P values \\
& $\mathbf{0 - 5}$ & $\mathbf{6 - 1 4}$ & $\mathbf{1 5 - 2 1}$ & $\mathbf{2 2 >}$ & \\
\hline S.viridans & $26 / 50$ & $10 / 42$ & $16 / 49$ & $194 / 489$ & 0.09 \\
& $51.0 \%$ & $23.8 \%$ & $32.7 \%$ & $39.7 \%$ & \\
\hline S.epidermidis & $9 / 50$ & $7 / 42$ & $13 / 49$ & $92 / 489$ & 0.62 \\
& $17.7 \%$ & $16.7 \%$ & $26.5 \%$ & $18.8 \%$ & \\
\hline Neisseria spp. & $4 / 50$ & $4 / 42$ & $5 / 49$ & $53 / 489$ & 0.72 \\
& $7.8 \%$ & $9.5 \%$ & $10.2 \%$ & $10.8 \%$ & \\
\hline Corynebacterium spp. & $7 / 50$ & $6 / 42$ & $3 / 49$ & $62 / 489$ & 0.70 \\
& $14.0 \%$ & $14.3 \%$ & $6.1 \%$ & $12.7 \%$ & \\
\hline Klebsiella pneumoniae & $4 / 50$ & $1 / 42$ & $0 / 49$ & $36 / 489$ & 0.27 \\
& $8.2 \%$ & $2.4 \%$ & $0 \%$ & $7.4 \%$ & \\
\hline
\end{tabular}

Table 2. Time dependence for the detection frequency of common aerobic microorganisms cultured from the oral cavity of HSCT patients

\begin{tabular}{|c|c|c|c|c|c|c|}
\hline Terms after HSCT, months & 0 & $1 \mathrm{mo}$ & $2 \mathrm{mo}$ & $3 \mathrm{mo}$ & $4 \mathrm{mo}$ & $\mathbf{P}$ \\
\hline S.viridans & $\begin{array}{l}50 \% \\
(50 / 100)\end{array}$ & $\begin{array}{l}29.5 \% \\
(43 / 146)\end{array}$ & $\begin{array}{l}33.7 \% \\
(57 / 169)\end{array}$ & $\begin{array}{l}45.0 \% \\
(58 / 129)\end{array}$ & $\begin{array}{l}43.7 \% \\
(38 / 87)\end{array}$ & 0.004 \\
\hline S.epidermidis & $16 \%(16 / 100)$ & $\begin{array}{l}10.3 \% \\
(15 / 146)\end{array}$ & $\begin{array}{l}23.7 \% \\
(40 / 169)\end{array}$ & $\begin{array}{l}20.9 \% \\
(27 / 129)\end{array}$ & $\begin{array}{l}26.4 \% \\
(23 / 87)\end{array}$ & 0.009 \\
\hline Neisseria spp. & $\begin{array}{l}12 \% \\
(12 / 100)\end{array}$ & $\begin{array}{l}6.2 \% \\
(9 / 146) \\
\end{array}$ & $\begin{array}{l}7.7 \% \\
(13 / 169)\end{array}$ & $\begin{array}{l}14.0 \% \\
(18 / 129)\end{array}$ & $\begin{array}{l}16.1 \% \\
(14 / 87)\end{array}$ & 0.06 \\
\hline Corynebacterium spp. & $\begin{array}{l}11.1 \% \\
12 / 100\end{array}$ & $\begin{array}{l}6.9 \% \\
10 / 146\end{array}$ & $\begin{array}{l}18.9 \% \\
32 / 169\end{array}$ & $\begin{array}{l}10.1 \% \\
13 / 129\end{array}$ & $\begin{array}{l}13.8 \% \\
12 / 87\end{array}$ & 0.02 \\
\hline Klebsiella pneumoniae & $\begin{array}{l}5.0 \% \\
(5 / 100)\end{array}$ & $\begin{array}{l}0.7 \% \\
(1 / 146)\end{array}$ & $\begin{array}{l}8.8 \% \\
(15 / 170)\end{array}$ & $\begin{array}{l}7.9 \% \\
(10 / 127)\end{array}$ & $\begin{array}{l}12.6 \% \\
(11 / 87)\end{array}$ & 0.003 \\
\hline
\end{tabular}

Note: The difference levels ( $\mathrm{p}$ values) were determined by the non-parametric Hi-square test. This time dynamics for 3 distinct bacterial species is also shown in Fig. 1. 

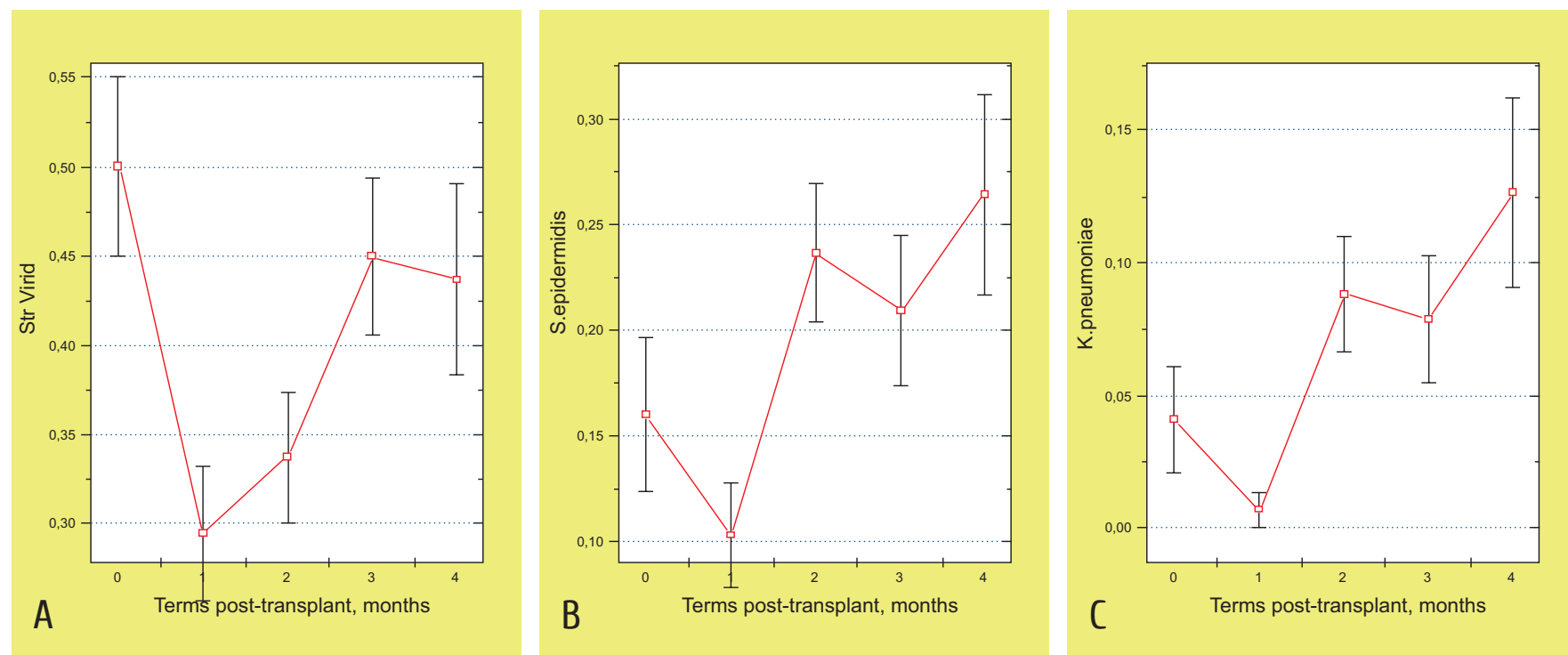

Figure. 1. Prevalence of S.viridans (A), S.epidermidis (B), and K.pneumoniae (C) in bacterial cultures within 1-4 months after HSCT

Abscissa, terms posttransplant (months). Ordinate, frequency of positive results. Points at the graph show $\mathrm{M}+\mathrm{m}$ values.

Table 3. Detection rates for some common oral microorganisms in HSCT recipients over 120 days post-HSCT: dependence on transplant characteristics and posttransplant complications

\begin{tabular}{|c|c|c|c|c|c|}
\hline Microbial species & S.viridans & S.epidermidis & Neisseria spp. & Corynebacterium spp. & $\begin{array}{l}\text { Klebsiella } \\
\text { pneumoniae }\end{array}$ \\
\hline Total positive cultures, \% & 196/531 (36.9\%) & 105/531 (19.8\%) & 54/531 (9.1\%) & $67 / 531$ (12.6\%) & 37/531 (7.0\%) \\
\hline $\begin{array}{l}\text { Transplant type: } \\
\text { Peripheral stem cells } \\
\text { Bone marrow }\end{array}$ & $\begin{array}{l}107 / 290 \text { (36.9\%) } \\
88 / 233 \text { (37.8\%) } \\
\text { P=0.39 }\end{array}$ & $\begin{array}{l}57 / 290(19.7 \%) \\
45 / 233(19.3 \%) \\
\\
\mathrm{P}=0.84\end{array}$ & $\begin{array}{l}30 / 290(10.4 \%) \\
24 / 233(10.3 \%) \\
P=0.90\end{array}$ & $\begin{array}{l}37 / 290(12.8 \%) \\
30 / 233(12.9 \%) \\
P=0.87\end{array}$ & $\begin{array}{l}14 / 290(4.8 \%) \\
22 / 233(9.4 \%) \\
\mathrm{P}=0.20\end{array}$ \\
\hline $\begin{array}{l}\text { Conditioning regimen: } \\
\text { Myeloablative } \\
\text { Non-myeloablative }\end{array}$ & $\begin{array}{l}106 / 295 \text { (35.9\%) } \\
89 / 231 \text { (38.5\%) } \\
P=0.54\end{array}$ & $\begin{array}{l}40 / 295 \text { (13.6\%) } \\
63 / 231 \text { (27.3\%) } \\
\mathrm{P}=8 \times 10^{\wedge} 5\end{array}$ & $\begin{array}{l}27 / 295(9.2 \%) \\
27 / 231(11.7 \%) \\
\mathrm{P}=0.34\end{array}$ & $\begin{array}{l}43 / 295 \text { (14.6\%) } \\
23 / 231 /(10.0 \%) \\
\mathrm{P}=0.11\end{array}$ & $\begin{array}{l}17 / 295(5.8 \%) \\
19 / 230(8.3 \%) \\
\mathrm{P}=0.26\end{array}$ \\
\hline $\begin{array}{l}\text { Oral mucositis } \\
\text { Reported } \\
\text { Absent }\end{array}$ & $\begin{array}{l}82 / 231(35.5 \%) \\
103 / 282(36.5 \%) \\
P=0.81\end{array}$ & $\begin{array}{l}44 / 231(19.1 \%) \\
58 / 282(20.6 \%) \\
P=0.67\end{array}$ & $\begin{array}{l}21 / 231(9.1 \%) \\
28 / 282(9.9 \%) \\
P=0.75\end{array}$ & $\begin{array}{l}34 / 231(14.7 \%) \\
28 / 282(9.9 \%) \\
P=0.10\end{array}$ & $\begin{array}{l}15 / 231(6.5 \%) \\
21 / 281(7.5 \%) \\
P=0.67\end{array}$ \\
\hline $\begin{array}{l}\text { FU0 } \\
\text { Yes } \\
\text { No }\end{array}$ & $\begin{array}{l}79 / 213(37.1 \%) \\
105 / 299 \text { (35.1\%) } \\
\mathrm{P}=0.65\end{array}$ & $\begin{array}{l}51 / 213(23.9 \%) \\
51 / 299(17.1 \%) \\
\mathrm{P}=0.06\end{array}$ & $\begin{array}{l}22 / 213(10.3 \%) \\
27 / 299(9.0 \%) \\
\mathrm{P}=0.62 \\
\end{array}$ & $\begin{array}{l}31 / 213(14.6 \%) \\
31 / 299(10.4 \%) \\
\mathrm{P}=0.15\end{array}$ & $\begin{array}{l}13 / 213(6.1 \%) \\
23 / 298(7.7 \%) \\
\mathrm{P}=0.48\end{array}$ \\
\hline $\begin{array}{l}\text { Acute GVHD grade 1-4 } \\
\text { Yes } \\
\text { No }\end{array}$ & $\begin{array}{l}32 / 101(31.7 \%) \\
29 / 76 \text { (38.2\%) } \\
\mathrm{P}=0.37\end{array}$ & $\begin{array}{l}19 / 101(18.8 \%) \\
15 / 76(19.7 \%) \\
P=0.88\end{array}$ & $\begin{array}{l}14 / 101(13.9 \%) \\
7 / 76(9.2 \%) \\
P=0.34\end{array}$ & $\begin{array}{l}12 / 101 \text { (11.9\%) } \\
10 / 76 \text { (13.2\%) } \\
\mathrm{P}=0.80\end{array}$ & $\begin{array}{l}9 / 101(8.9 \%) \\
10 / 76 \text { (13.2\%) } \\
\mathrm{P}=0.36\end{array}$ \\
\hline $\begin{array}{l}\text { Clinically significant infections } \\
\text { Yes } \\
\text { No }\end{array}$ & $\begin{array}{l}67 / 208 \text { (32.2\%) } \\
117 / 304(38.5 \%) \\
\mathrm{P}=0.146\end{array}$ & $\begin{array}{l}46 / 208 \text { (22.1\%) } \\
56 / 304(18.4 \%) \\
P=0.304\end{array}$ & $\begin{array}{l}16 / 208(7.7 \%) \\
33 / 304(10.9 \%) \\
\mathrm{P}=0.23\end{array}$ & $\begin{array}{l}21 / 208 \text { (10.1\%) } \\
41 / 304(13.5 \%) \\
\mathrm{P}=0.25\end{array}$ & $\begin{array}{l}21 / 206(10.2 \%) \\
15 / 305(4.9 \%) \\
P=0.02\end{array}$ \\
\hline
\end{tabular}




\section{Mucositis, febrile neutropenia and clinical infections}

In more than $50 \%$ of patients, oral mucositis was observed within early terms after HSCT. Our data have confirmed higher frequency of oral mucositis after myeloablative conditioning treat-ment $(181 / 330,54.9 \%)$ against $33.1 \%(80 / 242)$ following reduced-intensity conditioning $\left(\mathrm{p}=2 \times 10^{-7}\right)$. Moreover, higher occurrence of febrile neutropenia was found in the group of patients with mucositis (50.3\%) against $30.7 \%$ in mucositis-free cases $\left(p=4 \times 10^{-8}\right)$, as seen from Table 3. Taking into account similar terms of mucositis and dysbacteriosis ( $1^{\text {st }}$ month posttransplant), one could suggest infectious component for the oral inflammation. However, we did not reveal any significant correlations between mucositis rates, and frequency of positive cultures of the common microorganisms from oral mucosa (Table 3 ), thus suggesting a minimal role of these bacteria in genesis of the posttransplant oral inflammation. In addition, we have not revealed any significant correlations between presence of the major species of oral microflora, and acute skin GVHD (Table 3). Absence of correlations between bacterial landscape and main clinical complications may be connected with active antibacterial therapy over the period of post-transplant leukopenia (1-2 months post-HSCT).

Further, we have performed some comparisons between the frequencies of bacterial associations, rates of febrile neutropenia and clinically significant infections posttransplant. This survey has shown that the more frequent associations of $>3$ microbial species tends to correlate with higher FUO prevalence (Table 4). Increased incidence of FUO was also found after myeloablative conditioning $(\mathrm{p}=0.001)$, as well as in the group with oral mucositis $\left(\mathrm{p}=4 \times 10^{-8}\right)$, as well as in cases of skin aGvHD ( $p=0.002)$, thus reflecting evident inflammatory component in the both types of skin and mucosal damage, however, without any association with . Hence, early neutropenic fever is more likely associated with cytostatic chemotherapy and allogeneic HSCT, rather than with local clinically significant infections posttransplant.

Interestingly, the numbers of transplanted hematopoietic stem cells (CD34+ cells) have shown a distinct direct correlation with occurrence of early mucositis $\left(r=0.20 ; \mathrm{p}=8 \times 10^{7}\right)$ thus again suggesting a clear relation between oral mucositis and potential immune effects of allogeneic hematopoietic cells posttransplant.

\section{Microbial resistance}

Klebsiella is the mostly discussed bacterial pathogen with high prevalence of antibiotic-resistant strains. We have tested in vitro the resistance of K.pneumoniae isolates seeded from oral cavity of 11 HSCT patients in 2017 (Table 5). Majority of the isolates showed resistance for most antibiotics commonly used in septic HSCT patients. However, most of the K.pneumoniae isolates proved to be sensitive to amikacin, gentamycin and meropenem.

Of note, in the patient F.Z., the initial sensitive phenotype was 1 month later changed to polyresistance, except of amikacin and meropenem, thus, probably, reflecting its replacement by a resistant bacterial strain.

\section{Table 4. Frequency of FUO and microbial associations: effects of different HSCT parameters and posttransplant complications}

\begin{tabular}{|c|c|c|c|c|}
\hline Parameter & $\begin{array}{l}\text { FU0 ("fever of unknown origin") } \\
\text { incidence }\end{array}$ & $\begin{array}{l}\text { P significance } \\
\text { levels }\end{array}$ & $\begin{array}{l}\text { Frequency of different local } \\
\text { clinical infections }\end{array}$ & $\begin{array}{l}\text { P significance } \\
\text { levels }\end{array}$ \\
\hline $\begin{array}{l}\text { Number of microbial species } \\
\text { per a single sample } \\
0 \\
1 \\
2 \\
3>\end{array}$ & $\begin{array}{l}80 / 203(39.4 \%) \\
81 / 202(40.1 \%) \\
39 / 89(43.8 \%) \\
12 / 17(70.6 \%)\end{array}$ & 0.084 & $\begin{array}{l}91 / 203(44.8 \%) \\
72 / 202(35.6 \%) \\
37 / 89(41.6 \%) \\
8 / 17(46.1 \%)\end{array}$ & 0.274 \\
\hline $\begin{array}{l}\text { Conditioning regimen: } \\
\text { Myeloablative } \\
\text { Reduced intensity }\end{array}$ & $\begin{array}{l}1 \\
54 / 329(46.8 \%) \\
81 / 242(33.5 \%)\end{array}$ & 0.001 & $\begin{array}{l}127 / 329(38.6 \%) \\
103 / 242(42.6 \%)\end{array}$ & 0.34 \\
\hline $\begin{array}{l}\text { Stem cell source } \\
\text { Bone marrow } \\
\text { HSCT }\end{array}$ & $\begin{array}{l}106 / 252(42.1 \%) \\
127 / 315(40.3 \%)\end{array}$ & 0.29 & $\begin{array}{l}96 / 252(38.1 \%) \\
132 / 315 \text { (41.9\%) }\end{array}$ & 0.08 \\
\hline $\begin{array}{l}\text { Oral mucositis } \\
\text { Yes } \\
\text { No }\end{array}$ & $\begin{array}{l}\text { 139/261 (53.3\%) } \\
96 / 313(30.7 \%)\end{array}$ & $4 \times 10^{\wedge} 8$ & $\begin{array}{l}107 / 261(41.0 \%) \\
126 / 313(40.3 \%)\end{array}$ & 0.86 \\
\hline $\begin{array}{l}\text { Skin GVHD, grade } \\
0 \\
1 \\
2-3\end{array}$ & $\begin{array}{l}20 / 78(25.6 \%) \\
47 / 89(52.8 \%) \\
14 / 26(53.9 \%)\end{array}$ & 0.002 & $\begin{array}{l}43 / 78(55.1 \%) \\
38 / 89(42.7 \%) \\
12 / 26(46.2 \%)\end{array}$ & 0.375 \\
\hline $\begin{array}{l}\text { Cyclophosphamide for GVHD } \\
\text { prevention } \\
\text { Yes } \\
\text { No }\end{array}$ & $\begin{array}{l}174 / 425(40.9 \%) \\
59 / 116 \text { (50.9\%) }\end{array}$ & 0.06 & $\begin{array}{l}149 / 425(35.1 \%) \\
69 / 116(59.5 \%)\end{array}$ & $2 \times 10^{\wedge} 6$ \\
\hline
\end{tabular}




\section{Bacterial pathogens at the sites of dental infections}

In 10 cases, tooth extraction was performed during $1^{\text {st }}$ month after HSCT, due to acute pulpitis and local septic process. Bacterial isolates from the post-extraction wounds were obtained in 10 cases, and the following bacteria were detected: Pseudomonas aeruginosa in 3 samples, S.viridans in 2 cases, Neisseria spp., S.faecalis, S.epidermidis were found in other specimens. Of them, only P.aeruginosa is a well-known pathogenic agent to cause purulent local inflammation.

\section{Discussion}

Overall rates of positive microbial cultures from oral cavity were rather high $(61.8 \%)$. Cytotoxic damage to oral epithelium due to previous chemotherapy, as well as deep leukopenia after conditioning treatment and HSCT are the key pre-requisites for oral bacterial colonization [9]. However, conventional culturing of oral samples taken at different terms post HSCT (D-60 to D+120) have shown a sufficient decrease in cultivable oral microflora within $1^{\text {st }}$ month posttransplant. Such suppression of microflora could be readily explained by anti-microbial treatment administered during intensive cytostatic therapy of cancer $[10,11]$. In our study, a deep suppression was shown for S.viridans, S.epidermidis, and $K$. pneumoniae. The latter is the known Gram-negative pathogen causing infectious complications at later terms (2-4 months posttransplant), with a tendency for polyresistance for antibiotics, as confirmed in our study.

Microbial associations of 3 or more bacteria could be found in some samples. Of note, posttransplant clinically significant infections proved to be much more often in cases with $>3$ microorganisms found in the oral samples, thus suggesting the microbial associations to be a marker of suppressed antimicrobial immunity post-HSCT.

Like as other common posttransplant complications, clinical infectious conditions did not show any direct correlations with either positive oral bacterial cultures, or early post-transplant mucositis (Table 3 and 4). Rather, fever of unknown origin (FUO), an early inflammatory condition without clear infectious reason, had a distinct relationship with myeloablative treatment, oral mucositis, and skin GvHD. Oral mucositis may be, at least, in part, dependent on common herpesvirus activation post-HSCT [12].

Among common bacterial species found in oral cavity of the patients, Klebsiella pneumoniae is known to produce a number of polyresistant strains, as confirmed in our study (Table 5). This feature of K.pneumoniae is typical to nosocomial infections. Decreased rates of Klebsiella detection at early terms ( $1^{\text {st }}$ month) following HSCT could be explained by relative sensitivity of most endogenous bacterial populations

Table 5. Differential in vitro antibiotic sensitivity of K.pneumoniae isolates obtained from oral cavity after hematopoietic stem cell transplantation

\begin{tabular}{|c|c|c|c|c|c|c|c|c|c|c|c|c|}
\hline \multicolumn{2}{|c|}{ Initials/ date } & \multirow{2}{*}{ 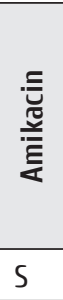 } & \multirow{2}{*}{ 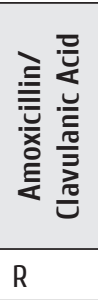 } & \multirow{2}{*}{ 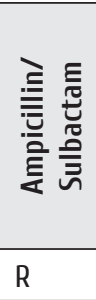 } & \multirow{2}{*}{ 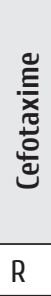 } & \multirow{2}{*}{ 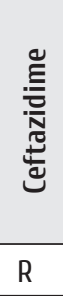 } & \multirow{2}{*}{ 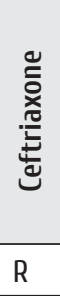 } & \multirow{2}{*}{ 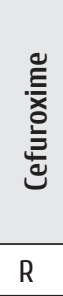 } & \multirow{2}{*}{ 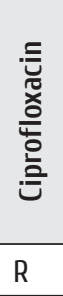 } & \multirow{2}{*}{ 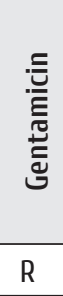 } & \multirow{2}{*}{ 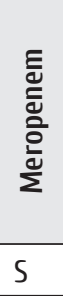 } & \multirow{2}{*}{ 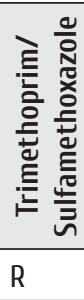 } \\
\hline V.A. & 13.02.17 & & & & & & & & & & & \\
\hline K.V. & 10.01.17 & $S$ & $\mathrm{R}$ & $\mathrm{R}$ & $S$ & $S$ & $S$ & $S$ & $\mathrm{R}$ & $S$ & $S$ & $\mathrm{R}$ \\
\hline G.E. & 08.08.17 & 5 & $\mathrm{R}$ & $\mathrm{R}$ & $\mathrm{R}$ & $\mathrm{R}$ & $\mathrm{R}$ & $\mathrm{R}$ & $\mathrm{R}$ & $S$ & $S$ & $\mathrm{R}$ \\
\hline G.E. & 04.09 .17 & 5 & $\mathrm{R}$ & $\mathrm{R}$ & $\mathrm{R}$ & $\mathrm{R}$ & $\mathrm{R}$ & $\mathrm{R}$ & $\mathrm{R}$ & $S$ & $S$ & $\mathrm{R}$ \\
\hline H.A. & 31.03 .17 & $\mathrm{R}$ & $\mathrm{R}$ & $\mathrm{R}$ & $\mathrm{R}$ & $\mathrm{R}$ & $\mathrm{R}$ & $\mathrm{R}$ & $\mathrm{R}$ & $\mathrm{R}$ & $\mathrm{R}$ & $\mathrm{R}$ \\
\hline B.V. & 15.08 .17 & $\mathrm{R}$ & $\mathrm{R}$ & $\mathrm{R}$ & $\mathrm{R}$ & $\mathrm{R}$ & $\mathrm{R}$ & $\mathrm{R}$ & $\mathrm{R}$ & $\mathrm{R}$ & $\mathrm{R}$ & $\mathrm{R}$ \\
\hline K.I. & 21.06 .17 & 5 & $\mathrm{R}$ & $\mathrm{R}$ & $\mathrm{R}$ & $\mathrm{R}$ & $\mathrm{R}$ & $\mathrm{R}$ & $\mathrm{R}$ & $S$ & $S$ & $\mathrm{R}$ \\
\hline K.I. & 26.06 .17 & $S$ & $\mathrm{R}$ & $\mathrm{R}$ & $\mathrm{R}$ & $\mathrm{R}$ & $\mathrm{R}$ & $\mathrm{R}$ & $\mathrm{R}$ & $S$ & $S$ & $\mathrm{R}$ \\
\hline F.Z. & 15.05 .17 & $S$ & $S$ & $S$ & $S$ & $S$ & $S$ & $S$ & $S$ & $S$ & $S$ & $\mathbf{R}$ \\
\hline F.Z. & 13.06.17 & 1 & $\mathbf{R}$ & $\mathbf{R}$ & $\mathbf{R}$ & $\mathbf{R}$ & $R$ & $R$ & $\mathrm{R}$ & $\mathbf{R}$ & $S$ & $\mathrm{R}$ \\
\hline F.Z. & 19.06.17 & $S$ & $\mathbf{R}$ & $\mathbf{R}$ & $\mathbf{R}$ & $\mathbf{R}$ & $\mathbf{R}$ & $\mathbf{R}$ & $\mathbf{R}$ & $\mathbf{R}$ & $S$ & $\mathbf{R}$ \\
\hline I.A. & 15.05 .17 & $S$ & $\mathrm{R}$ & $\mathrm{R}$ & $\mathrm{R}$ & $\mathrm{R}$ & $\mathrm{R}$ & $\mathrm{R}$ & $\mathrm{R}$ & $S$ & $S$ & $\mathrm{R}$ \\
\hline I.A. & 22.05 .17 & $S$ & $\mathrm{R}$ & $\mathrm{R}$ & $\mathrm{R}$ & $\mathrm{R}$ & $\mathrm{R}$ & $\mathrm{R}$ & $\mathrm{R}$ & $S$ & 5 & $\mathrm{R}$ \\
\hline I.A. & 29.05 .17 & $S$ & $\mathrm{R}$ & $\mathrm{R}$ & $\mathrm{R}$ & $\mathrm{R}$ & $\mathrm{R}$ & $\mathrm{R}$ & $\mathrm{R}$ & 5 & $S$ & $\mathrm{R}$ \\
\hline I.A. & 03.07.17 & 5 & $\mathrm{R}$ & $\mathrm{R}$ & $\mathrm{R}$ & $\mathrm{R}$ & $\mathrm{R}$ & $\mathrm{R}$ & $\mathrm{R}$ & $S$ & 5 & $\mathrm{R}$ \\
\hline L.E. & 15.05.17 & $\mathrm{R}$ & $\mathrm{R}$ & $\mathrm{R}$ & $\mathrm{R}$ & $\mathrm{R}$ & $\mathrm{R}$ & $\mathrm{R}$ & $\mathrm{R}$ & $S$ & $S$ & $\mathrm{R}$ \\
\hline A.I. & 24.10 .17 & 5 & $\mathrm{R}$ & $\mathrm{R}$ & $\mathrm{R}$ & $\mathrm{R}$ & $\mathrm{R}$ & $\mathrm{R}$ & $\mathrm{R}$ & 5 & 5 & $\mathrm{R}$ \\
\hline K.A. & 29.05 .17 & $S$ & $\mathrm{R}$ & $\mathrm{R}$ & $S$ & $S$ & $S$ & $S$ & $\mathrm{R}$ & $S$ & $S$ & $\mathrm{R}$ \\
\hline K.A. & 13.06.17 & $S$ & $R$ & $\mathrm{R}$ & $S$ & $S$ & $S$ & $\mathrm{R}$ & $\mathrm{R}$ & 1 & $S$ & \\
\hline
\end{tabular}

Note: R, resistance; S, sensitivity of the microorganism; I, intermediate values. 
to routine decontaminating therapy. At later terms $\left(2^{\text {nd }}\right.$ and $3^{\text {rd }}$ months) the sensitivity-adapted antibiotic treatment in the patients with prolonged infectious complications under the ICU conditions, may cause selection of Klebsiella strains with extended resistance spectrum as, it was revealed in our F.Z. patient at 5-6 months after HSCT.

Therefore, phenotypic and molecular monitoring of standard lactamase genes in clinical isolates before and after HSCT may further elucidate the mechanisms of resistance selection among Klebsiella and other Gram-negative bacteia, aiming for development of combined treatment schedules [13].

In this respect, the role of oral bacterial infection in development of mucositis and GvHD still remains unclear. Meanwhile, over last decades, a crucial role of gut microbiome and altered intestinal mucosa due to broad-spectrum antibacterial therapy becomes more clear and clinically confirmed, both for infectious complications and acute GvHD $[14,15,16]$.

\section{Conclusion}

Cytotoxic damage of oral mucosa during intensive chemotherapy may create sufficient prerequisites for bacterial colonization. Moreover, antibacterial prophylaxis in HSCT patients causes deep suppression of oral microflora during $1^{\text {st }}$ month post-HSCT, despite severe leukopenia in the patients. Known antibacterial pathogens, e.g., K.pneumoniae, or P.aerugunosa are revealed in oral cavity within 1-3 months posttransplant.

The consequences of combined anticancer and antibacterial treatment in HSCT patients deserve further studies, in particular, its correlation with mucositis, acute GvHD which may be still underlied by mixed microbial and viral infections. Bacterial imbalance post-HSCT may be a pre-requisite for additional anti-infectious therapy in complex clinical conditions involving infectious/cytotoxic/autoaggressive pathogenetic components. Significant shifts in common bacterial landscape caused by immunotoxic treatment and antibacterial therapy enable growth of other bacterial and fungal pathogens that should be studied in details by means of NGS techniques which should reveal, e.g., anaerobic pathogenic bacteria in posttransplant conditions.

\section{References}

1. Hull MW, Chow AW. Indigenous microflora and innate immunity of the head and neck. Infect Dis Clin N Am 2007; 21: 265-282.

2. Hegde MC, Kumar A, Bhat G, Sreedharan S. Oral microflora: a comparative study in HIV and normal patients. Indian J Otolaryngol Head Neck Surg. 2014; 66(Suppl 1): S126-S132.

3. Aas JA, Paster BJ, Stokes LN, Olsen I, Dewhirst FE. Defining the normal bacterial flora of the oral cavity. J. Clin. Microbiol. 2005; 43(11): 5721-5732.

4. Chukhlovin AB, Pankratova OS. Opportunistic microflora at unusual sites: marker pathogens in severe posttransplant immune deficiency. Cell Ther Transplant. 2017; 6(4): 28-41.
5. Marena C, Zecca M, Carenini ML, Bruschi A, Bassi ML, Olivieri P, Azzaretti S, Locatelli F. Incidence of, and risk factors for, nosocomial infections among hematopoietic stem cell transplantation recipients, with impact on procedure-related mortality. Infect Control Hosp Epidemiol. 2001;22(8):510-517.

6. Lahei AMGA, de Soet JJ, von dem Borne PA, Kuijper EJ, Kraneveld EA, van Loveren C, Raber-Durlacher JE. Oral bacteria and yeasts in relationship to oral ulcerations in hematopoietic stem cell transplant recipients. Support Care Cancer. 2012; 20:3231-3240.

7. Czirók E, Prinz GY, Dénes R, Reményi P, Herendi A. Value of surveillance cultures in a bone marrow transplantation unit. J Med Microbiol. 1997;46(9):785-791.

8. Vavilov VN, Averianova M.Yu. Bondarenko SN, Stancheva NV, Zubarovskaya LS, Afanasyev BV. Bacterial infections within early period after allogeneic bone marrow transplantation. Ter Arkhiv, 2015; 87(7): 88-93 (In Russian).

9. Grigoriants AP, Rabinowitch IM, Chukhlovin AB. Stomatological problems and infectious complications after hematopoietic stem cell transplantation. Cell Ther Transplant 2017; 7(2):10-19.

10. Bergmann OJ. Alterations in oral microflora and pathogenesis of acute oral infections during remission-induction therapy in patients with acute myeloid leukaemia. Scand J Infect Dis. 1991;23(3):355-66.

11. Jones LR, Toth BB, Keene HJ. Effects of total body irradiation on salivary gland function and caries-associated oral microflora in bone marrow transplant patients. Oral Surg Oral Med Oral Pathol. 1992;73(6):670-676.

12. Pankratova OS, Chukhlovin AB, Shiryaev SN, Eismont YA, Vavilov VN, Zubarovskaya LS, Afanasyev BV. Herpesviruses and oral ulcerations in hematopoietic SCT recipients. Bone Marrow Transplantation. 2013; 48:1364-1365.

13. Fritzenwanker $M$, Imirzalioglu $C$, Herold $S$, Wagenlehner FM, Zimmer KP, Chakraborty T. Treatment Options for Carbapenem- Resistant Gram-Negative Infections. Dtsch Arztebl Int. $2018 ; 115(20-21): 345-352$.

14. Blijlevens NMA, Donnelly JP, De Pauw BE. Mucosal barrier injury: biology, pathology, clinical counterparts and consequences of intensive treatment for haematological malignancy: an overview. Bone Marrow Transplantation (2000) $25,1269-1278$.

15. Weber D, Jenq RR, Peled JU, Taur Y, Hiergeist A, Koestler J, Dettmer K, Weber M, Wolff D, Hahn J, Pamer EG, Herr W, Gessner A, Oefner PJ, van den Brink MRM, Holler E. Microbiota disruption induced by early use of broad-spectrum antibiotics is an independent risk factor of outcome after allogeneic stem cell transplantation. Biol Blood Marrow Transplant. 2017; 23(5):845-852.

16. Goloshchapov OV, Kucher MA, Chukhlovin AB. Gut microbiome in hematopoietic stem cell transplantation: patient- and treatment-related factors. Cell Ther Transplant. 2018; 7(4):16-28. 


\title{
| Высеваемость бактерий со слизистой ротовой полости после трансплантации гемопоэтических стволовых клеток: зависимость от характеристик пациента и терапевтических факторов
}

\author{
Алексей Б. Чухловин ${ }^{1}$, Анна А. Спиридонова ${ }^{2}$, Ирина Б. Баранова ${ }^{3}$, Артур П. Григорьянц ${ }^{3}$, \\ Мария Д. Владовская ${ }^{1}$, Людмила С. Зубаровская ${ }^{1}$, Борис В. Афанасьев ${ }^{1}$ \\ ${ }^{1}$ НИИ детской онкологии, гематологии и трансплантологии им. Р. М. Горбачевой, Санкт-Петербург, Россия \\ ${ }^{2}$ Отделение клинической микробиологии, Первый Санкт-Петербургский государственный медицинский университет \\ им. акад. И. П. Павлова, Санкт-Петербург, Россия \\ ${ }^{3}$ Кафедра челюстно-лицевой хирургии, Первый Санкт-Петербургский государственный медицинский университет \\ им. акад. И. П. Павлова, Санкт-Петербург, Россия
}

\section{Резюме}

Нормальная аэробная и факультативно-анаэробная микробиота, колонизирующая слизистую оболочку рта, часто выявляется в клинических лабораториях. Ее состав может быть важным показателем иммунокомпромиссных состояний. Данные параметры мало изучены у пациентов после трансплантации гемопоэтических клеток (ТГСК). Целью настоящей работы была оценка выявляемости обычной аэробной и факультативно-анаэробной микробиоты, культивированной из биоматериала полости рта до ТГСК и, по клиническим показаниям, в течение 4 мес. после этого лечения.

\section{Пациенты и методы}

Мы оценили результаты посевов образцов, взятых из ротовой полости у 202 больных с онкогематологическими и врожденными заболеваниями в возрасте от 1 до 69 лет, которым была проведена аллогенная ТГСК. Анализ проводился для 3 возрастных групп: 1-5, 6-14, 15-21 и >22 лет.

\section{Результаты}

После 630 проведенных бактериологических исследований, позитивные результаты культивирования получены в $61.8 \%$ образцов. Наиболее частыми микроорганизмами были следующие: S.viridans 245/630 (38.9\%); K.pneumoniae 42/630 (6.7\%); S.epidermidis 120/630 (19.1\%); Neisseria spp. 66/630 (10.5\%); Corynebacterium spp. 78/630 (12.4\%). Частота выявления микроорганизмов зависела от времени после ТГСК, а именно отмечено снижение высеваемости S.epidermidis, Corynebacterium spp. и Klebsiella spp. в течение 1-го месяца после ТГСК, что можно объяснить эффективной ранней антибактериальной деконтаминацией пациентов, начиная с момента кондиционирования. Нами показано, что частота высеваемости S.viridans и K.pneumoniae в этих образцах была различной для отдельных возрастных групп, будучи существенно повышенной у детей самого младшего возраста (до 5 лет) и у взрослых пациентов (>22 лет), по сравнению со старшими детьми и подростками. Высеваемость K.pneumoniae в образцах из полости рта оказалась существенно повышенной через 2-3 месяца после ТГСК, что сопровождалось тяжелыми инфекционными осложнениями и наличием резистентности клинических изолятов Klebsiella к большинству антибиотиков. По клиническим показаниям проведена экстракция зубов в 10 случаях в течение 1-го мес. после ТГСК. Посевы раневого отделяемого из десен показали наличие Pseudomonas aeruginosa в 3 образцах, S.viridans в 2 случаях.

\section{Выводы}

Иммунотоксические эффекты цитостатической терапии и анализ микробиоты после ТГСК заслуживают дальнейших исследований, в том числе анализ биологического разнообразия микробиоты полости рта посредством секвенирования гена $16 \mathrm{~S}$ rRNA. Эти результаты могут стать основой для рациональной антибактериальной терапии при ТГСК.

\section{Ключевые слова}

Онкогематология, дети, химиотерапия, трансплантация гемопоэтических стволовых клеток, бактериальные культуры, факторы риска. 